\title{
КОМУНІКАТИВНІ СТРАТЕГІї ФОРМУВАННЯ ПОЗИТИВНОГО ІМІДЖУ НАТО В АНГЛО-УКРАЇНСЬКОМУ ПЕРЕКЛАДІ
}

Стаття присвячена виявленню специбіки відтворення комунікативних стратегій формування позитивного іміджу НАТО в англо-украйнському перекладі. Актуальність дослідження зумовлена необхідністю встановлення інвентарю комунікативних стратегій успішного спілкування як компонента професійної діяльності політичних діячів, важливістю з'ясування особливостей корпоративної комунікації окремої організації для формування ї̈ позитивного іміджу та виявлення специфіки відтворення комунікативних стратегій формування позитивного іміджу в перекладі. У статті розв'язано коло завдань: окреслені поняття іміджу та комунікативної стратегії; виокремлені комунікативні стратегії, які сприяють формуванню позитивного іміджу НАТО; репрезентовано варіанти перекладу комунікативних стратегій формування позитивного іміджу НАТО на матеріалі промов ексГенерального секретаря Андерса Фог Расмуссена.

Ключові слова: імідж, комунікативні стратегї, промови, НАТО, англоукраїнський переклад.

Starukh V. Communicative Strategies of Forming NATO Positive Image in the Aspect of English-Ukrainian Translation. The article focuses on the NATO positive image formative communicative strategies and peculiarities of their EnglishUkrainian translation. The author points out that solving the issue of communicative image realization is one of the most important ones since positive image creates positive attitude of society towards either a person or an organization as a whole.

The topicality of the article is caused by the fact that nowadays the issue of rendering communicative strategies of positive image formation in the speeches of NATO officials has not been fully studied yet. The author argues that the text of a speech should be created, taking into account all linguistic and extralinguistic peculiarities. Consequently, the instruments of communicative strategies which form positive image will differ. Moreover, it is important to identify addressees and a type of speech.

The author takes a close look at the definitions of image and communicative strategies. Thus, image is a coherent, qualitatively identified representation of an object firmly existing and realized in the collective or / and individual consciousness. Communicative strategies are identified as the best possible implementation of speaker's intentions in order to achieve a specific goal of communication, including control and choice of effective ways of communication and flexible change of them in a particular situation.

(C) Cтapyx B. O., 2020 
The findings of the research are the peculiarities of English-Ukrainian translation of positive image formative communicative strategies in the speeches of NATO officials. The article makes a study of the speeches of NATO ex-General Secretary Anders Fogh Rasmussen who often resorts to communicative strategies of cooperation. It outlines the factors which influence the positive image formation. Information recognition, its conformity with public expectations, prejudice dispelling and successful positioning of the organization in front of addressees are among them.

Key words: image, communicative strategies, speeches, NATO, English-Ukrainian translation.

\section{Вступ}

Наразі питання формування іміджу посідає одне з найголовніших місць у прагненнях створити відповідне позитивне ставлення суспільства до окремої людини або організації. Тому дослідженням іміджу присвячені роботи багатьох учених, серед яких Л. М. Пелепейченко (2008), А. Ю. Панасюк (2008), О. С. Іссерс (2008), О. С. Кубрякова (2008), Г. Г. Почепцов (1999).

Для такої організації, як НАТО, імідж є важливим складником діяльності, адже від ставлення населення країн-членів та країн-союзників залежить не тільки місце НАТО на світовій арені, але й подальша перспектива залучення нових країн до лав організації та підтримка з боку суспільства політики організації.

Одним із способів донесення певної інформації до суспільства діячами НАТО є промови. Так вони прагнуть підкреслити політику ‘відкритих дверей’ організації, надати повну й вичерпну інформацію стосовно останніх кроків організації з метою розвіювання чуток і міфів, запевнити людей, що саме вони є рушійною силою, та що організація потребує участі кожної людини для досягнення спільної мети.

На сьогодні проблема комунікативної реалізації іміджу в промовах потребує більш ретельного дослідження. Відомо, що текст промови має бути побудованим і реалізованим з урахуванням усіх лінгвальних та екстралінгвальних особливостей, отже, інвентар комунікативних стратегій створення іміджу в тексті промови буде варіюватися. Крім того, необхідно враховувати вид промови й аудиторію, на яку вона буде спрямована. Таким чином, з огляду на те, що організація є міжнародною, особливого значення набуває ще й питання про відтворення в перекладі комунікативних стратегій формування позитивного іміджу в тексті промов діячів НАТО. Вищезазначене свідчить про актуальність теми дослідження. 
Мета наукової розвідки - виявити особливості відтворення в англо-українському перекладі комунікативних стратегій формування позитивного іміджу НАТО. Для досягнення поставленої мети необхідно розв’язати таке коло конкретних завдань: 1) окреслити визначення 'імідж’ та 'комунікативна стратегія'; 2) встановити комунікативні стратегії формування позитивного іміджу НАТО; 3) виявити особливості відтворення комунікативних стратегій формування позитивного іміджу НАТО в англо-українському перекладі. Матеріалом нашого дослідження слугували промови екс-Генерального секретаря НАTO А. Ф. Расмуссена (Rasmussen, 2012; Rasmussen, 2013).

\section{Методи дослідження}

Методи було обрано відповідно до мети й завдань дослідження. На пошуково-ознайомлювальному та підготовчому етапах у процесі добору теоретичної літератури й фактичного матеріалу для аналізу основними були методи цілеспрямованої вибірки, узагальнення та систематизації.

На аналітичному етапі було використано метод аналізу й синтезу, метод прагматичного аналізу, метод лінгвістичного спостереження, критичного дискурсивного аналізу та контекстуального аналізу, метод перекладацького аналізу. Результати подано з використанням сукупності прийомів узагальнювального методу.

\section{Виклад основного матеріалу}

Перш ніж перейти до викладення основного матеріалу дослідження, звернемося до тлумачення основних понять.

Під іміджем розуміють цілісний, якісно визначений образ певного об’єкта, стійко наявний і відтворюваний у масовій і / чи індивідуальній свідомості (Олянич, 2007). Імідж містить у собі значний обсяг емоційно забарвленої інформації про об’єкт сприйняття та спонукає до певної соціальної поведінки.

У теорії мовної комунікації під стратегією мовленнєвого спілкування розуміють оптимальну реалізацію інтенції мовця щодо досягнення конкретної мети спілкування, тобто контроль і вибір дієвих ходів спілкування і гнучкої їх видозміни в конкретній ситуації (Бацевич, 2004). Ефективна комунікація передбачає постійний вибір комунікантом певної моделі поведінки (комунікативних стратегій), що в конкретній ситуації буде найбільш сприятливою в досягненні поставленої мети. 
Стратегії формування іміджу належать до типу комунікативних стратегій і здійснюються шляхом комунікації в межах інформативності повідомлень із застосуванням вербальних і візуальних засобів, адже завдання презентації тісно пов'язані з інтенцією адресанта, а формування іміджу здійснюється з використанням адресантом певних прийомів, від яких залежить не тільки позиціонування, але й підтримання позитивного ставлення до організації з боку суспільства (Пелепейченко, 2008).

У теорії комунікації немає універсальної класифікації комунікативних стратегій. О. С. Іссерс поділяє комунікативні стратегії на ієрархії мотивів і цілей, найбільш значущих для мовця. Основна стратегія - семантична, або когнітивна, наприклад, підкорення адресата, дискредитація третьої особи тощо. Допоміжна стратегія - прагматична, що обслуговує всі цілі самопрезентації та самовираження й існує в таких різновидах: побудова іміджу, створення емоційного настрою тощо. Діалогові стратегії зумовлені бажанням адресанта керувати комунікативною ситуацією (Иссерс, 2008). Також виділяють кооперативні та некооперативні стратегії мовленнєвого спілкування (Бацевич, 2004).

Наразі перейдемо до практичних результатів дослідження.

У першій проаналізованій промові було виявлено такі особливості (Rasmussen, 2013). Відомо, що Афганістан уже давно викликає занепокоєння серед керівників багатьох держав. Тому намагання НАТО розв’язати проблеми безпеки на території цієї країни свідчить про те, що ії першочерговим завданням $є$ безпека всіх держав, що передусім сприяє створенню позитивного іміджу організації: I will talk about our highest operational priority, Afghanistan. - Я буду говорити про наше найрріоритетніше завдання - Афганістан. Уживання прикметника в найвищому ступені порівняння highest позиціонує Афганістан як центральний елемент у планах організаціі. У перекладі прагматика висловлювання повністю зберігається, адже дібрано відповідний еквівалент до ключового слова речення, хоча й опущена лексична одиниця operational, що, проте, ніяк не спотворює його зміст.

Характерним $є$ вживання займенника our, що наголошує на важливості кооперації та згуртованості націй навколо спільної мети HATO: Our troops, our nations, and the whole international community have made an unprecedented investment in blood and treasure in Afghanistan. - Наші війська, наші нації і все міжнародне співтовариство 
робить безпрецедентний внесок у людські та матеріальні ресурси Афганістану. Поетичне висловлювання blood and treasure підкреслює серйозне ставлення до проблем у країні, адже усвідомлюється висока ціна, яку необхідно платити за нестабільну ситуацію в Афганістані.

Ще одним прикладом вираження відчуття єдності, відчуття гордості за досягнення спільної мети є такий: We can be proud of what we have accomplished in Afghanistan. - Ми можемо пишатися тим, чого ми досягли в Афганістані.

Проте в бік НАТО лунають звинувачення в постійному втручанні в Афганістан з метою контролю над цією країною під приводом встановлення миру та спокою. У такому разі важливо розвіяти чутки, для чого варто окреслити основні функції НАТО в Афганістані: NATO's job is not to build a perfect state. We went to Afghanistan to protect our security by helping Afghans take control of their own security. - Завдання НАТО полягає не в побудові ідеальної держави. Ми увійшли в Афганістан, щоб захистити нашу безпеку, допомагаючи населенню иієї країни взяти під контроль свою власну безпеку. За допомогою дієслова to protect та іменника security транслюється повідомлення щодо пріоритетності безпеки в усіх країнах, що, безумовно, допомагає формувати позитивний імідж.

Позитивне ставлення формується також на основі довіри. Довіра до будь-якої організації $є$ більшою, якщо факти базуються на власному досвіді. Наприклад, у своїй промові А. Ф. Расмуссен інформує про ситуацію в Афганістані, спираючись на власний досвід побаченого в країні: I saw that Afghan soldiers are increasingly capable, confident and in command. I saw that ISAF's role has already largely shifted to training, advising and mentoring. And I saw that this shift is ... happening ... throughout the country. - Я побачив, що солдати в Абганістані стають все більш квалібікованими, упевненими та здатними контролювати ситуацію в країні. Я побачив, що роль ІСЕФ вже значною мірою полягає в забезпеченні процесу навчання, надаванні консультацій та наставництві. I я побачив, що цей прогрес відбувається на території всієї країни. У цьому прикладі, аби підкреслити персоналізацію повідомлення, використано паралельні граматичні конструкції з анафорою I saw.

Наведення результатів роботи організації також сприяє формуванню позитивного іміджу: Afghan soldiers and police now have the lead for the security of $\mathbf{8 7 \%}$ of the population. They deliver up to $\mathbf{9 0 \%}$ of their own training. And they lead 95\% of all operations. - Наразі питанням безпеки 
87\% населення опікуюються солдати та поліція. Вони виконують приблизно 90\% своїх навчань. I вони очолюють 95\% усіх операцій. Цифри, факти завжди підсилюють силу повідомлення та засвідчують дієвість роботи.

У другій проаналізованій промові було виявлено такі особливості (Rasmussen, 2012). На сьогодні для громадянина кожної країни важливо жити в безпечній державі, що має алгоритм дій для захисту від ворогів. Саме тому у виступі на засіданні ПА НАТО А. Ф. Расмуссен наголошує на важливості існування такої: We need to have the right forces and capabilities to deter and defend against any threat to keep our nations safe. - Ми повинні мати достатні сили й можливості для стримування будь-якої загрози і для захисту наших країн. У перекладі було опущено частину речення to keep our nations safe 3 метою уникнення тавтології.

Важливим фактором для створення позитивного іміджу НАТО $€$ можливість запропонувати шляхи для розв'язання будь-якої проблеми: We have already decided how to do just that. We have our roadтар. - Ми вже вирішили, як ие зробити. Унас є стратегічний план.

Також у промові звертається увага на досягнуті результати; це свідчить про те, що НАТО працює ефективно: We have already made encouraging progress. - Ми вже зробили прогрес, який надихає.

Промова відрізняється наявністю патріотичних гасел та закликів до дій на кшталт: We need to take on greater responsibility for our security, not less. - Ми повинні нести більшу відповідальність за нашу безпеку, але не меншу;

So we need to continue to keep our defences strong. - Отже, нам необхідно продовжувати підтримувати наші засоби оборони непохитниMu;

That's why we need to kеep our Alliance strong. - Саме тому ми повинні зберігати міць нашого Альянсу.

У вищезазначених реченнях слова security, defences, strong вказують на пріоритетність питань безпеки та на спроможність організації iii гарантувати.

У наступних конструкціях використання модальних дієслів підкреслює рішучість, спрямовану на виконання поставленої мети й завдань: We need to maintain the momentum. - Нам необхідно рухатися в томуж темпі; 
We must continue to push ahead with those projects we have agreed. Ми повинні продовжувати просувати ті проєкти, які ми затверди$\pi u$;

And we must push forward with the other projects that we have identified as being suitable for multinational approaches. - I ми повинні просувати інші проєкти, які ми визначили необхідними для багатьох інших країн.

Комунікативні стратегії кооперації є важливими для створення позитивного іміджу. Зокрема, унаслідок використання антонімів together - alone, together - on their own у промові виражається заклик до єднання країн: By joining together to acquire capabilities, nations will be able to afford what they cannot do alone. - Об'єднуючись з метою реалізаціі потенціалу, країни будуть мати змогу зробити те, що не матимуть змоги втілити в життя поодиниі;

Despite the current economic difficulties, Alliance continues to provide the framework that enables Allies to achieve greater security together than they could ever achieve on their own. - Незважаючи на проблеми з економікою, Альянс продовжує бути основою, яка надає змогу його членам досягти більших успіхів у наданні захисту разом, ніж окремо.

Готовність працювати разом, перспективи й переваги з боку НАТО позиціонують ії як відкриту організацію, що, беззаперечно, створює позитивний імідж.

Наголос на особистості як на рушійній силі організації робить організацію ближчою до людей, підкреслює важливість кожного, виражає потребу організації міжнародного масштабу навіть в одному індивіді: NATO пеeds уоu. Your choices will determine whether NATO will be as successful in the future as it was in the past. And whether we can protect our values and our security in the future as effectively as we have done in the past. I count on you to make the right choices for our future. - Bu потрібні НАТО. Ваш вибір визначить, чи буде НАТО такою ж успішною організацією у майбутньому, як ие було в минулому. І чи можемо ми захистити наші иінності і нашу безпеку в майбутньому так само ефективно, як ми ие робили в минулому. Я розраховую на вас $і$ на ваш правильний вибір на користь нашого майбутнього.

Широка географія співробітництва НАТО підкреслює їі готовність до співпраці з представниками різних країн: Every day, NATO forces are working shoulder-to-shoulder from Afghanistan to Kosovo and 
off the coast of Somalia. They have also developed the habit of working with partners from outside the Alliance. - Кожного дня військовослужбовці НАТО пращюють пліч-о-пліч з військовослужбовиями різних країн від Афбганістану і до Косово та узбережжя Сомалі. Звичайною справою є співпраия з крайнами, які не є членами Альянсу. Звісно, здатність до кооперації позитивно впливає на створення іміджу.

\section{Висновки}

Отже, у результаті дослідження було виявлено, що в промовах екс-Генеральний секретар А. Ф. Расмуссен використовує комунікативні стратегії створення позитивного іміджу, однією з найбільш розповсюджених з яких є комунікативна стратегія кооперації. Урахування таких факторів, як упізнаваність інформації, іiі відповідність очікуванням соціального оточення, розвіювання упередженої думки й вдале позиціювання організації перед адресатами відповідно до тієї ролі, яку вона виконує, також сприяє формуванню позитивного іміджу.

Основною проблемою в процесі перекладу тексту промов $€$ збереження прагматики, вибір правильного інструментарію, добір відповідної лексики для трансляції повідомлення зі збереженням інтенцій автора. Переклад допоміжних стратегій фахівець має здійснювати шляхом використання лексики з нейтральним емоційним забарвленням, щоб уникнути збільшення комунікативного ефекту допоміжних стратегій і зберегти значущість основних стратегій. Допоміжні стратегії - це лише інструмент формування іміджу, що реалізує інтенцію адресата, тому необхідно чітко усвідомлювати й оцінювати їхню роль.

Перспективою подальших розвідок $є$ виявлення особливостей англо-українського перекладу комунікативних стратегій формування позитивного іміджу НАТО в промовах наступника А. Ф. Расмуссена $€$. Столтенберга з метою їх порівняння та дослідження розвитку та змін інструментарію створення позитивного іміджу.

\section{ЛІТЕРАТУРА}

1. Бацевич, Ф. С. (2004). Основи комунікативної тінгвістики. Київ: Академія. 2. Иссерс, О. С. (2008). Коммуникативные стратегии и тактики русской речи. Москва: Издательство ЛКИ. 3. Кубрякова, Е. С. (2008). К определению понятия имиджа. Вопросы когнитивной тингвистики, 1, 5-11. 4. Олянич, А. В. (2007). Презентационная теория дискурса. Москва: Гнозис. 5. Панасюк, А. Ю. (2008). Формирование имиджа: стратегия, психотехнологии, психотехники. Москва: Омега-Л. 6. Пелепейченко, Л. М. (2008). Мовна комунікація в діяльності сил охорони правопорядку: 
Теоретичні засади галузевої комунікації. Харків: АВВ МВС України. 7. Почепцов, Г. Г. (2001). Профессия: имиджмейке. Санкт-Петербург: Алетейя. 8. Afghanistan: Worth the Cost. Retrieved from https://www.nato.int/cps/en/natohq/opinions_100598. htm? selectedLocale=fr. 9. Keynote speech. Retrieved from https://www.nato.int/cps/en/ natohq/opinions_91210.htm.

\section{REFERENCES}

1. Bacevich, F. S. (2004). Osnovy komunikatyvnoi linhvistyky [The basis of communicative linguistics]. Kyiv: Academiia [in Ukrainian]. 2. Issers, O. S. (2008). Kommunikativnye strategii i taktiki russkoj rechi [Communicative strategies and tactics in the Russian language]. Moscow: LKI Publishing House [in Russian]. 3. Kubriakova, E. S. (2008) K opredeleniju ponjatija imidzha [Determining the notion of image]. Voprosy kognitivnoj lingvistiki Cognitive linguistics issues, 1, 5-11 [in Russian]. 4. Oljanich, A. V. (2007). Prezentatsionnaja teorija diskursa [Presentational theory of discourse]. Moscow: Gnozis [in Russian]. 5. Panasjuk, A. U. (2008). Formirovanie imidzha: strategija, psihotehnolohii, psihotehniki [Image formation: strategy, psychotechnologies, psychotechnics]. Moscow: Omega-L [in Russian]. 6. Pelepeichenko, L. M. (2008). Movna comunikatsiia $v$ diialnosti syl okhorony pravoporiadku: Teoretychni zasady haluzevoi komunikatsii [Lingual communication in the activities of law-enforcement agencies: Theoretical basis of professional communication]. Kharkiv: Academy of the Interior Troops of the Ministry of Internal Affairs of Ukraine [in Ukrainian]. 7. Pochepcov, G. G. (2001). Professija: imidzgmejker [Occupation: image maker]. Saint Petersburg: Aletejja [in Russian]. 8. Afghanistan: Worth the Cost. Retrieved from https:// www.nato.int/cps/en/natohq/opinions_100598.htm?selectedLocale=fr [in English]. 9. Keynote speech. Retrieved from https://www.nato.int/cps/en/natohq/opinions_91210.htm [in English].

Старух Вікторія Олександрівна - старший викладач кафедри філології, перекладу та стратегічних комунікацій, Національна академія Національної гвардії України; майдан Захисників України 3, м. Харків, 61168, Україна.

Tel.: 0958025127

E-mail: viktoriia.starukh@gmail.com

http://orcid.org/ 0000-0002-3194-2389

Starukh Viktoriia Oleksandrivna - Senior Lecturer at the Department of Philology, Translation and Strategic Communications, National Academy of the National Guard of Ukraine; Zakhysnykiv Ukrainy square, 3, Kharkiv, 61168, Ukraine.

Надійшла до редакції 10 вересня 2020 року

\section{CITATION}

ДСТУ 8302:2015: Старух В. О. Комунікативні стратегії формування позитивного іміджу НАТО в англо-українському перекладі. Лінгвістичні дослідження: зб. наук. пр. Харк. нац. пед. ун-ту імені Г. С. Сковороди. Харків, 2020. Вип. 53. С. 85-93. DOI: https://doi.org/10.34142/23127546.2020.53.08

APA: Старух, В. О. (2020). Комунікативні стратегії формування позитивного іміджу НАТО в англо-українському перекладі. Лінгвістичні дослідження, 53, 85-93. DOI: https://doi.org/10.34142/23127546.2020.53.08 